\title{
Justice in Pedagogical Interactions as a Factor of Mental Health of Participants in Educational Process of Participants in Educational Process
}

\author{
Lilia Klochek $1 *$ [0000-0002-6450-3374], Tetyana Telychko 2 [0000-0002-6916-2273] \\ ${ }^{I}$ Volodymyr Vynnychenko Central Ukrainian State Pedagogical University, Kropyvnytskyi, Ukraine \\ ${ }^{2}$ Humanitiesand Pedagogical College Mukachevo State University, Mukachevo, Ukraine \\ *klochekl55@i.ua
}

\begin{abstract}
The article under consideration is devoted to psychological and pedagogical study of the factor of mental health of participants of educational process, precisely, the establishment of pedagogical interaction between them on the basis of equity and objectivity. Mental health has been defined as a state of psychological stability and emotional well-being of an individual, which had been caused by equity of social interactions and appreciative attitude of its participants to one another. It has been testified that mental health of pupils is established and improved in the process of pedagogical interaction due to fair, impartial, respectful attitude of a teacher towards them. It has been clarified, that justified actions of a teacher affect psycho-emotional state of pupils, increase the productivity of their activities and development of subjectivity. On the other hand, unjustified actions cause negative feelings and are accompanied with emotions of rejection, anger, indignation. It has been clarified that in the process of pedagogical interactions pupils are harmonized with a fair teacher, achieve social and psychological balance, emotional comfort, which has a positive effect on their mental health.
\end{abstract}

Keywords: mental health, emotional well-being, fair attitude, participants in educational process, pedagogical interaction.

\section{INTRODUCTION}

The problem of mental health of a personality has always been urgent for various spheres of scientific study. From the point of view of philosophy mental health of a person is realized in a harmonious combination of physical and spiritual health. In addition to actualization of a problem of leading a healthy lifestyle, a significant part is devoted to ethic and cultural aspects of existence of personality in the system «person - world», where attention has been concentrated on the idea of full-fledged development and existence [1]. Mental health is usually considered in medicine as absence of mental disorders, which affects succesful course of cognitive processes, the development of self-esteem, the adequacy of human behavior and its ability to respond to various life circumstances [2].

There is a view that a harmonious psychophysical development of a person, that is the combination of physical and mental health, can be ensured by active involvement into physical education, especially in school years [3] and in adolescence - during professional training, in the period of intense physical growth and personal development [4]. Emphasis is placed on the selection of effective pedagogical methods, didactic techniques, application of which promotes the development of physical capabilities of schoolchildren and students, as well as strengthens the inner position of their personality, forms an attitude to support health as the whole.

Recently, a new direction of pedagogical study has been distinguished known as pedagogy in health. The attention of researchers who study the problems of forming and maintaining health of younger generation, has been focused on the study of healthy lifestyles, social, economic and environmental conditions for its implementation. In addition to the problems of physical improvement of pupils, development of skills and effective means aimed at strengthening own health, the motivation for physical and spiritual improvement has also been actualized. An 
integrated approach has been defended towards understanding of human health as a complex phenomenon, containing the following components: physical, mental, spiritual, emotional health [5].

The research topic in pedagogy and psychology is mental health. Various ideas of scientists towards the problem of mental health agree that it is the state which enables individuals to perceive reality effectively, to function fully, to produce adequate behavioral expressions, to be in harmony with oneself and with the world. Among the problems concerning the violation of mental health, the following have been intensified, namely: the effect of stress factors on the individual, his psychological burnout, the counter of which lies in development of the ability to control own emotions and regulate behavioral expessions [6]. We tend to consider and define mental health in a value paradigm as a state of balance and emotional well-being of an individual, which is determined by the value attitude and is strengthened in the process of establishing constructive social interactions, in particular interactions in educational process.

Positive emotions arise by the feeling of dignity, which emerges in response to satisfaction of the need to obtain worthy reward for the results of one's own activity, expected appreciation by the surrounders for achievements of anindividual, impartial and respectful attitude to it by others. In a broad sense, equity brings emotional comfort, harmonizes a person's life and strengthens his mental health. It is achieved in the process of interaction with others.

In interdisciplinary context "equity" is considered as the process of non-interfering with the rights of everyone; ability of social institutions to encourage a person for his her contribution into socially useful activity, ability of a subject of interaction to assign proper measure of reward or punishment for his her actions and deeds [7].

Equity is expressed in social interactions, which are established in the process of communication and common activity, when their parts demonstrate an impartial attitude to one another and achieve understanding. Factors of mutual fair attitude among participants of social interaction are their maintenance of norms of equity, encouragement to act impartially. Cognitions that allow to assess adequately the situation of interaction; such qualities in the structure of character of its participants as the lack of selfishness, envy, bias [8]. Achieving justice is accompanied with positive emotional reactions, while injustice causes a number of negative, sometimes destructive experiences [9].

In pedagogical interaction justice is established in the process of joint activity between teachers and pupils together with subject-subject interactions. They are established in the process of organization of educational process. Usually scientists, actualizing the problem of justice in terms of pedagogical activities, focus on the issues of objective reflective analysis of students' academic achievements made by teachers, objective assessment of the quality of academic and educational requirements, appreciative attitude to each student, a combination of insistence and empathy in attitude to students [7].

However, there are some contradictions, which lead to inequitable actions and deeds. It can often be demonstrated by teacher's inadequate assessment of pupils' academic achievements, as well as in expression of evaluative statements towards their personalities, unjustified criticism, absence of teacher's tact. Excessive dominance of a teacher can also occur in the process of study, together with ignorance of their initiatives, disregard of emotional feelings, which prevents the establishment of feedback between participants of educational process, achievement of the desired result of pedagogical interaction [10]. The considered information mentioned above, has substantiated the problem of resolving conflicts and restoring justice. As it is widely known, everyday experience of injustice leads to negative feelings of people, encouraging to reconsider and re-find a source of positive emotions [11].

Modern world trends in humanization of education encourage teachers to be tolerant, fair to their students, sensitive to their requests. Establishment of pedagogical interactions based on the participants' value attitude to each other is a key to emotional well-being of both parts, the achievement and strengthening of their mental health on this basis.

The article aims at the study of equity peculiarities in the process of pedagogical interaction between teachers and pupils, which influences mental health of the latter. Research tasks: 1) to substantiate methodological basis of the study of equity in pedagogical interaction among participants of educational process; 2) to establish correlation of influence between teacher's justified expressions with pupil's mental health in the process of pedagogical interactions by means of empirical study.

\section{RESEARCH METHODOLOGY}

Research methodology is based on values approach, issues about a person as the highest value, the attitude to another as to self-worth [12], moral self-regulation of interpersonal relationships [13], value-normative regulation of interactions of participants in the educational process [14]. The essence of value approach in the study of influence of justice on mental health of participants of pedagogical interaction, is that emotional well-being of participants of educational process is achieved through a 
value attitude of a teacher to pupils, the establishment of psychological balance in their relationship, the feeling of satisfaction from established communicative interaction. In the process of evaluation of teacher's objective and impartial actions students are filled with a sense of justice, which determines the state of psychological comfort and emotional balance [15].

The study of impact on pupils' mental health through teacher's justified attitude has been carried out by authors applying empirical method of O.O. Gulevich «Questionnaire to study the attribution of traits of a person who committed a fair / unfair act», adopting it to the aim of our study. In the author's variant this technique has been applied to obtain information about the manner pupils evaluate situations of fair or unfair attitude to others and to themselves, as well as to establish a list of qualities attributed to a just or unjust person [8]. Considering the tasks set before, we had to disclose the importance of pupils' attitude and feelings towards teacher's fair or unfair actions in the process of pedagogical interaction. In this part, fundamental basis of the methodology was quite appropriate for implementation of formulated research goal. In addition, in the process of research, we have revealed how these attitudes affect the emotional wellbeing of pupils and the state of their mental health [16].

The research has been carried out in three sections. The first section gave possibility to pupils to recall those situations, when teachers had treated them fair. At the same time pupils mentioned precise emotions which had arisen as the result. The information mentioned above made it possible to establish how the psycho-emotional state of pupils is affected by impartial actions and values of a teacher.

The second section predetermined actualization of those memories of pupils when teachers treated them unfair. Pupils have also been suggested to recall what emotions followed these situations. It was important to obtain information about whether the facts of injustice in the educational process affected the mental health of its participants, precisely pupils.

In the process of research respondents graded justified $\backslash$ unjustified actions of teachers according to 10 -point scale. Number 10 stands for situations associated with purely justified actions of a teacher. Grades from 9 to 6 expressed gradual decrease of teacher's equity; grades ranging from 5 to 2 - gradual increase of injustice; 1 expressed totally unfair actions of a teacher.

The third section focused on obtaining information about what traits pupils associate with a fair teacher, and whether they have a desire to be like a teacher. The analysis of obtained data made it possible to investigate the extent of harmony in relationship with a fair teacher, and thus achieve social and psychological balance, emotional comfort and well-being. Thus, applied method enabled to reveal pupils' perception of fair or unfair attitude of a teacher in the process of pedagogical interaction and the extent of this impact on their mental health.

The experimental study has been carried out on the basis of general secondary educational establishments of the central region of Ukraine. About 215 schoolchildren aged from 14 to 16 have been involved. This age category has been chosen due to the fact that at this age the individual is particularly sensitive to unfair attitude of others, which affects psycho-emotional state and behavioral reactions.

\section{RESEARCH RESULTS}

In the process of conducting an empirical study, it has been revealed particular fair and unfair actions pupils focus on. Quantitative data are shown in Table 1.

As it can be seen from Table 1, 22,79 \% of pupils, analizing fair actions of a teacher, recalled situations, of having been properly evaluated by a teacher for the results of their academic activity. 33,02\% of respondents regarded teacher's understanding of pupils as the expression of equity. $14.88 \%$ gave special importance to teacher's nonassessive attitude to qualities of pupil's personality. The positive attitude of a teacher to any pupil regardless of his or her behaviour has also been considered as fair for 17, 21 $\%$ of experiment participants.

Unfair actions of a teacher, as those that are negatively perceived by pupils and cause unpleasant memories, have been actualized as follows. For $26.98 \%$, the situation when a teacher inadequately evaluates pupil's academic achievements is unacceptable. At the same time, $11.16 \%$ emphasize purposeful underestimation of grades. Increased demands of a teacher as a method of punishment causes rejection for $7.91 \%$ of respondents. $30.23 \%$ of respondents find it especially unpleasant to treat some pupils indulgently at the same time detesting the others. Investigation of peculiarities of pupils' attribute to fairlunfair teacher as to themselves some qualities is represented in Table 2.

In the process of research it has been established the following. 74,42\% of pupils consider a fair teacher as erudite specialist in his subject. The same characteristic feature is typical for unfair teacher according to 70,69\% of pupils under research. The quality of friendliness is given to a fair teacher by $85,58 \%$ of pupils and $55,81 \%$ - to unfair. For $67.91 \%$ of pupils, a fair teacher is a purposeful person who does not change decisions, while $58.61 \%$ of pupils consider an unfair teacher as such. For $94.88 \%$, the most significant is kindness as teacher's characteristic 
feature, while only $21.6 \%$ of respondents consider an unfair teacher as such. $77.67 \%$ prefer the humanity of a fair teacher, and $50.70 \%$ of pupils attribute this quality to an unfair teacher. $85.58 \%$ of schoolchildren consider a fair teacher to be reasonable and balanced, and $66.98 \%$ of respondents associate such quality with unfair teacher.
$96.74 \%$ of schoolchildren consider a fair teacher and $60.93 \%$ an unfair teacher to be sociable and able to explain clearly the correctness of pedagogical actions.

Table 1. Quantitative indicators of pupils' assessment of fairlunfair actions of teachers

\begin{tabular}{|c|l|c|c|}
\hline N & Pupils' ssessment of teacher's actions & Abs. & P \% \\
\hline & \multicolumn{1}{|c|}{ Assessment of fair actions of a teacher } & 22,79 \\
\hline 1 & Objective assessment of pupils' academic activity & 49 \\
\hline 2 & Understanding by a teacher of certain circumstances of a pupil & 71 & 33,02 \\
\hline 3 & Lack of evaluative attitude of a teacher to personal qualities of pupils & 32 & 14,88 \\
\hline 4 & Values of all pupils, regardless of their achievement or degree of guilt & 37 \\
\hline & \multicolumn{1}{|c|}{ Assessment of unfair actions of a teacher } & 58 \\
\hline 1 & Inadequate assessment of pupils' academic achievements & 24 & 17,21 \\
\hline 2 & Deliberate underestimation & 17,16 \\
\hline 3 & $\begin{array}{l}\text { Increased demandingness as a method of punishment for irresponsible attitude to study } \\
\text { or negative behavior }\end{array}$ & 17 & 7,91 \\
\hline 4. & Disrespectful attitude towards some pupils and positive and indulgent towards the others & 65 & 30,23 \\
\hline
\end{tabular}

Table 2. Quantitative indicators of attribution of personal qualities by pupils to fairlunfair teacher and to themselves

\begin{tabular}{|l|l|l|l|l|}
\hline $\mathrm{N}$ & Personality quality & $\begin{array}{l}\text { Attributed by pupils to fail } \\
\text { teacher,\% } \\
\text { unfair teacher,\% }\end{array}$ & own personality,\% \\
\hline 1 & Erudition & 74,42 & 70,69 & 62,79 \\
\hline 2 & Friendliness & 85,58 & 55,81 & 77,64 \\
\hline 3 & Goal-oriented & 67,91 & 58,61 & 58,61 \\
\hline 4 & Kindness & 94,88 & 21,6 & 74,88 \\
\hline 5 & Humanity & 77,67 & 50,70 & 77,21 \\
\hline 6 & Mind & 85,58 & 66,98 & 67,91 \\
\hline 7 & Sociability & 96,74 & 60,93 & \\
\hline
\end{tabular}

However, the participants of research determined to what extent the qualities which they had attributed to a teacher (fair and unfair) are represented in the structure of their own personality. It has been revealed that $62.79 \%$ of schoolchildren consider themselves erudite, $77.64 \%$ friendly, $58.61 \%$ goal-oriented, $74.88 \%$ kind, $77.21 \%$ humanistic, $67.91 \%$ balanced, and $97,67 \%$ sociable.

\section{RESULTS AND DISCUSSIONS}

Obtained quantitative results of carried out research make it possible to conclude that for a third of pupils, the teacher's ability to interact, understanding of their problems, individual feelings, level of preparation for the lesson, etc. is of extreme importance. In their comments to the answers given in registration forms, the respondents stated that a fair teacher is empathetic and tolerant, tends to find an individual approach to each of them in different situations of school life.
Pupils have testified that they feel positive emotions during communication with such a teacher, appreciate his openness and lack of emotional tension in the relationship, absence of fear of being punished for not completing the task.

A rather smaller number of pupils, associate justice of a teacher with an objective assessment of study outcomes, the quality of educational tasks. Since investigated experiment is realized by age category for which the motivation to study is somewhat less important than desire to realize the need for social interactions, only a quarter of respondents actualize the problem of obtaining justified grades for study outcomes. In their explanations, pupils confirmed that the fact of impartial attitude of a teacher becomes a source of their positive experiences, increases the motivation to study, activates to further improvement as subjects of cognition. Receiving rewards for activity results is accompanied with 
the emergence of a positive emotional background of pupils, which resonates with the results of other studies [17].

To a less extent, the respondents actualized teacher's positive attitude towards any pupil, as well as non-estimative attitude to personal qualities of pupils. Such deeds of a teacher, associated with his emotional restraint in terms of qualifying feeling of pupils, find positive reviews by the latter. As we can see, pupils prefer the actions of a fair teacher who does not emotionally perceive pedagogical situation and chooses appropriate tactics of behavior, but rationally comprehends it and is guided by moral motivation in interactions with pupils. In their statements, pupils shared not only their sympathies for such a teacher, but also commented on how such interaction affects the quality of their lives. They are dominated by an optimistic mood, a desire emerges not to disappoint a teacher with their actions, the vitality increases and there is no internal imbalance. These features are indicators of mental health, and therefore, it can be argued that the equity of the teacher's actions contributes to the achievement of this state of pupils.

Unjustified actions of a teacher perceived by pupils rather negatively. This can be confirmed by the comments that accompanied the second section of studies. As the results show, a third of respondents find offensive the teacher's contempt for less successful pupils and demonstratively lenient attitude to excellent students. Such injustice was particularly acute among pupils because of their feeling of being devalued. Negative feelings arose with memories about situations when a the teacher assessed educational tasks inadequately. Such indignation arose in view with the urgent need to get a deserved reward (evaluation) for their work. It was accompanied with emotions of anger, which is an undesirable, destructive phenomenon for the growing personality. A rather smaller number of respondents focused on such manifestations of an unfair teacher as purposeful underestimation and increasing demands as a method of punishment for irresponsible attitude to study and bad behavior.

Concerning the latter, schoolchildren having fixed their unpleasant attitude to such actions of a teacher, did not express strong negative emotions, but had recalled such situation indifferently. From this respect, teacher's inequity generates a variety of feelings of students: moderate rejection; strong aggressive - anger, rage; not expressed indifference.

All these emotions are not constructive. They unbalance [18] pupil's personality, do not focus on understanding of own mistakes and overcoming shortcomings, but only form negative attitude towards a teacher. This does not contribute to mental health in any way, but only creates problems for their intellectual and personal growth.
Regarding the study of peculiarities of pupils' attributing to a fair and unfair teacher some personal qualities, mainly positive, a greater extent of pupils associate them with a fair teacher. This applies to such qualities as kindness, humanity, friendliness, balance, sociability - those that ensure productive pedagogical interaction on the basis of humanity, openness and dialogue. It is worth noting that an unfair teacher, whose actions are unacceptable to students, also, in their opinion, has a number of these qualities, but in a relatively less extent.

Analyzing the way these features have been determined by students in the structure of their own personality, and establishing the discrepancy between quantitative indicators [19] of qualities of pupils and the same qualities of a fair $\backslash$ unfair teacher, we came to the following conclusion. A smaller gap between these qualities is observed in their attribution to a fair teacher and to own personality. A much larger gap is observed as a result of comparing the qualities of an unfair teacher and the qualities of pupils. Information under consideration makes it possible to generalize that pupils harmonize more with a fair teacher. They perceive himlher positively, appreciate the humane attitude to themselves and always remember with gratitude the situations connected with himlher. The authors have testified that the feeling of gratitude is one of key factors of mental health of a growing up individual, which gives him selfconfidence [20], contributes to the establishment of social and psychological balance, making up conditions for emotional comfort and psychological well-being of pupils, as the basis of mental health.

\section{CONCLUSIONS}

Investigation of the problem of equity in pedagogical interaction of teachers and pupils as a factor of mental health of the latter gives grounding to the following conclusions. 1. Mental health is a state of psychological balance and emotional well-being of an individual, which is affected by justice of social interactions, value attitude of participants to each other. 2. In educational process, teachers being unfair often act in the way that harms emotional well-being of pupils, brings them out of a state of psychological balance. 3 . In accordance with value approach, mental health of pupils is achieved and strengthened through the value attitude of a teacher towards them, which is associated with the feeling of pleasure by a growing up personality from the established communicative interaction. 4.Analyzing fair actions of teachers, pupils focus mainly on the facts of their objective assessment of academic achievements as well as teacher's understanding of various circumstances of pupils in making pedagogical decisions. The pupils' analysis of unfair actions of teachers has revealed the significance of impossibility to get a well-deserved mark for the results of their study and demonstartion of prejudice against some pupils on the 
contrast of being easy on others. It has been clarified that fair actions of a teacher had a positive effect on psychoemotional state of pupils, helped to increase their productivity, while unfair actions were associated with negative emotions of rejection, anger, resentment and indifference. 5. In the process of pedagogical interaction pupils tend to harmonize with a fair teacher, who is a bright example of a valued attitude towards others; the precise personality whose relationships are built on a positive emotional basis, creating favorable conditions for development and improvement of mental health of pupils.

\section{REFERENCES}

[1] Bilanov, O. S. (2020), "Filosophical approches to understanding the categories of health / disease", International Journal of Innovative Technologies in Social Science, vol. 4(25), pp. 8-11.

[2] Nel'son-Anderson, D.L. and Uoltere, S.V. (2001), Domashnij medicinskij spravochnik [Home medical dictionary], Izdatel'stvo EKSMO - Press, Moskva, Sova, Sankt-Peterburg.

[3] Jinfu Xu (2019), "The Promotion Effect of School Physical Education on Physical Health of Young Children", Proceedings of the 3rd International Conference on Culture, Education and Economic Development of Modern Society, April, available at: https://www.atlantis-press.com/proceedings/iccese$19 / 55915945$

[4] Xiaojun Li (2015), "The harmonious generation between Orienteering and Physical Education in Colleges and Universities", Proceedings of the 2015 International Conference on Industrial Technology and Management Science, November, available at: https://www.atlantis-press.com/proceedings/itms$15 / 25843274$

[5] Lukianchenko, M.I. (2010), Pedahohika zdorovia: teoriia ta praktyka [Health pedagogy: theory and practice], Redaktsiino-vydavnychyi viddil Drohobytskoho derzhavnoho pedahohichnoho universytetu imeni Ivana Franka, Drohobych, Ukraïna.

[6] Lei Shi (2015), The study of the influence of the work stress on job burnout of knowledge-based employee Based on the regulating effect of emotional intelligence, Proceedings of the 2015 International Conference on Industrial Technology and Management Science, November, available at: https://doi.org/10.2991/itms-15.2015.396

[7] Klochek, L.V. (2018), Spravedlivist' u pedagogichnij vzacmodiï: psihologichnij vimir [Justice in pedagogical interaction: the psychological dimension], Machulin, Harkiv, Ukraïna.

[8] Gulevich, O.A. (2011), Social'naya psihologiya spravedlivosti [Social psychology of justice], Izdatel'stvo «Institut psihologii RAN», Moskva, Rossiya.

[9] De Cremer D. and Ruiter R.A.G. (2003), "Emotional reactions toward procedural fairness as a function of negative information", The Jornal of Social Psychology, vol. 143, pp. 793-795.

[10] Qiongqin Jiang, Tian Jin, Wenguang Song and Haiyu Chen (2020), "Research on Cultivating Undergraduates in the Computer Science Based on Students", Engineering and Manufacturing, № 6, pp. 32-39.

[11] Mikula G., Petri B. and Tanzer N. (1990), "What people regard as unjust: types and structures of everyday experiences of injustice", European Journal of Social Psychology, vol. 20, pp. 133-149.

[12] Prosande€va, L.€. (2011), Geneza samocinnosti osobistosti $\mathrm{V}$ procesi socializacii [The genesis of personal self-worth in the process of socialization], Kiïv, Ukraïna.

[13] Ribalka, V.V. (2011), Psihologiya chesti ta gidnosti osobistosti: kul'turologichni ta aksiologichni aspekti [Psychology of honor and dignity of the individual: cultural and axiological aspects], Institut obdarovanoï ditini, Kiïv, Ukraïna.

[14] Bulah, I.S. (2003), Psihologiya osobistisnogo zrostannya pidlitkiv: realï ta perspektivi [Psychology of adolescent personal growth: realities and prospects], Nilan LTD, Vinnicya, Ukraïna.

[15] Bekh, I.D. (2012) Osobistist' u prostori duhovnogo rozvitku [Personality in the space of spiritual development], Akademvidav, Kiïv, Ukraïna.

[16] Nor Safika Mohd Shafiee and Sofianita Mutalib, (2020), "Prediction of Mental Health Problems among Higher Education Student Using Machine Learning", International Journal of Education and Management Engineering, vol. 10, no. 6, pp. 1-9. DOI: 10.5815/ijeme.2020.06.01

[17] Garbarino J. "The impact of anticipated reward upon cross-age tutoring", Journal of Personality and Social Psychology. vol. 32(3), pp. 421-428.

[18] Mashud, M. A. A. Barman, S. C. Bhuiyan, M. R. A. And Md. Serajul Islam (2013), "Design and Implementation of Three Phase Unbalanced Voltage 
Motor Controller", International Journal of Intelligent Systems and Applications, vol. 5, no. 10, pp. 35-42. DOI: $10.5815 /$ ijisa.2013.10.05

[19] Makrufa Sh. Hajirahimova and Aybeniz S. Aliyeva (2017), "About Big Data Measurement Methodologies and Indicators", International Journal of Modern Education and Computer Science, vol. 9, no. 10, pp. 19. DOI: 10.5815/ijmecs.2017.10.01

[20] Huaiyuan Fang and Qingfang Cao (2016), Appreciation Makes Students Grow Healthy and Self-confident, Proceedings of the 6th International Conference on Electronic, Mechanical, Information and Management Society, April 2016, available at: https://www.atlantispress.com/proceedings/emim-16/25853504 